\title{
Will God Make Me Rich? An Investigation into the Relationship between Membership in Charismatic Churches, Wealth, and Women's Empowerment in Ghana
}

\author{
Sara Gundersen \\ Department of Economics, Valparaiso University, 1400 Chapel Drive, Valparaiso, IN 46383, USA; \\ Sara.Gundersen@valpo.edu
}

Received: 15 May 2018; Accepted: 17 June 2018; Published: 19 June 2018

\begin{abstract}
In recent decades, there has been an explosion in the growth of Pentecostal churches in Ghana, many of which preach that belief in God will translate into material wealth for both men and women. While some have argued that women in these churches are likely to be more empowered due to female leadership and focus on the individual, others have argued that this may not translate to the typical congregant's experience. After all, members of the Pentecostal church subscribe to the belief that wives should "submit to their husbands" (Biblia n.d.). In this study, I used the 2014 Demographic Health Survey to directly test whether women who identify as Pentecostal/Charismatic/Evangelical have a higher level of empowerment as measured by autonomy in decision making. I found that they exhibit significantly less decision-making power than other Christian women in making big household purchases and on their own healthcare. This exists both before and after controlling for wealth. Thus, the notion that Pentecostal women are more empowered than other Christians appears to be misguided.
\end{abstract}

Keywords: Pentecostalism; Ghana; women's empowerment

\section{Introduction}

Ghana's Pentecostal churches (also known as neo-Pentecostal or Charismatic churches) ${ }^{1}$ have been growing rapidly in recent years (Gifford 2004b; Heaton et al. 2009) with membership estimated at over $40 \%$ of the population. Beck and Gundersen (2016) find that earned income varies among women by religious denomination in Ghana, and that women identifying as Pentecostal earn more income than the Presbyterian based group after controlling for socioeconomic variables. Because of the churches' focus on individualism and the presence of female leaders, one may assume women who belong to Pentecostal churches are more empowered than women of other religions, and that this may contribute to the earnings differential. This may be enhanced by the focus on acquisition of material wealth. However, the theoretical link between membership and women's empowerment is unclear, as

1 The term Pentecostal may present some confusion. While Ghana's newer Pentecostal churches contain some similarities to traditional Pentecostalism, they differ in many ways. For example, they do not necessarily practice 'initial evidence': (Soothill 2007). Difficulties also arise with the use of the term Charismatic, as these churches differ from Charismatic Protestant and Catholic wings in that they are largely nondenominational. Still, they are typically grouped together due to shared features such as a focus on the individual, spirits, and material prosperity, and scholars often refer to the group as "neo-Pentecostal." The Demographic Health Survey asks about religious denomination as a country-specific question and in 2008 began aggregating this group as Pentecostal/Charismatic/Evangelical in Ghana. For this paper, I refer to the group as Pentecostal in general and Pentecostal/Charismatic/Evangelical where using data but acknowledge the heterogeneity in the group. 
wives are taught that they should "submit" to their husbands and the experiences of female leadership does not necessarily extend to the typical "born-again" experience (Soothill 2010).

This is the first study to explicitly test for differences in women's empowerment within Pentecostal churches in an African context. Using the 2014 Ghana Demographic Health Survey, I was able to test for differences in women's empowerment by religious denomination while controlling for socioeconomic variables such as wealth, education, and working status. Women's empowerment is measured by decision making over large household purchases, visits to family or relatives, spending of their own or their husband's earnings, and their own health care. While women of most religions exhibit more decision-making power than Traditional/Spiritual/Animist religions with regard to family visits, women who identify as Pentecostal/Charismatic/Evangelical have significantly less decision-making power than other Christian women when it comes to big household purchases and their own healthcare. Thus, the notion that Pentecostal women are more empowered than other Christians is not supported by this data.

This paper proceeds as follows: Section 2 provides background information and Section 3 describes the theoretical links between membership in Pentecostal churches and women's empowerment. Section 4 addresses the definition and measurement of women's empowerment. Section 5 describes the data and Section 6 provides the econometric methodology and results. Section 7 discusses the findings of the study and offers a summary conclusion.

\section{Background}

Ghana is deeply religious, with traditional religions existing well before the introduction of Christianity (Addai 2000; Heaton et al. 2009). This religious quality continues today, with Gallup determining Ghana to be the most religious country in the world in 2012 (WIN-Gallup International 2012). Although significant portions of the population continue to practice traditional religions and Islam, Christianity is both the largest and fastest-growing group. In particular, Ghana has not been immune to the rapid growth of Charismatic or neo-Pentecostal churches occurring throughout the African continent. ${ }^{2}$ Gifford (2004b) describes how in Ghana, membership in these churches grew at rates of up to 100\% between 1986 and 1992 (versus 17\% for total religious membership during the same time period). Heaton et al. (2009) report similar growth from 1993-2003, where non-Catholic and non-mainline Protestant Christians increased from $16.9 \%$ of the population to over $41 \%$. Using sample weights in the Ghana Demographic Health Survey I found that women who identify as Pentecostal/Charismatic/Evangelical represented 40.2\% of the population in 2014.

Among the major tenets of these churches is a focus on material wealth (Gifford 2004a, 2004b; Heaton et al. 2009). Gifford writes: "Just talking to these Christians, or studying their sermons, testimonies, and literature, one finds recurring words like progress, prosperity, breakthrough, success; their opposites, closed doors, poverty, sickness, setback, hunger, joblessness. Probably the biggest word in this Christianity is 'breakthrough"' (Gifford 2004b, p. 171). He notes that prosperity in this context means abundant rather than merely adequate wealth. Heaton et al. (2009) write about an instance where "the message is crassly portrayed on a poster outside a large church depicting a large mansion and an exotic sports car with the phrase "with God all things are possible" (p. 74). They note that continual exposure to this message could legitimize pursuit of material goods and argue that it may even lead to greater personal efficacy (p. 74). While scholars have speculated that this can lead to greater empowerment among women, the theoretical links are unresolved. The next section describes this in the context of Ghana. 


\section{Theoretical Links}

Although it is commonly assumed that the expansion of Pentecostalism will benefit women, Martin (2001) wrote about a "Pentecostal Gender Paradox" in a global context, with competing theoretical forces between membership in Pentecostal churches and women's empowerment. This paradox is unresolved globally and in Ghana, where women traditionally serve as subordinates to their husbands and are disadvantaged economically (Awumbila 2006) and with respect to education, credit, equipment, high-productivity activities, and access to food (Wrigley-Asante 2008). Additionally, they face high rates of intimate partner violence (Oduro et al. 2015) and have little decision-making power (Boateng et al. 2014).

On the one hand, Pentecostal churches in Ghana remove many traditional barriers to female leadership. Along with some high profile positions, Gifford (2004a) notes that women are often in lower level leadership positions, such as "ushers, choristers, prayer warriors and evangelists" (p. 183). However, Soothill (2010) argues that what appears as female empowerment among high profile women in the church, such as pastors' wives or the female pastor Christie Doe Tetteh, may not reflect the experiences of born-again women ${ }^{3}$ (ibid., p. 90). Indeed, "When asked if it was the churches' attitude towards women's 'empowerment' and the acceptance of women leaders that had attracted them to the charismatic movement, most of them said 'no'. Rather, it was the power of charismatic prayer" 4 (ibid.).

Another argument is that the churches' focus on development of individuals provides an opportunity for women to legitimize personal pursuits, especially given the churches' teachings on wealth and prosperity. Soothill (2010) writes, "Whilst the equality of men and women's spiritual experiences was recognised almost a century before by the early Pentecostal and Holiness movements (Powers 1999; Lawless 1988), Ghana's new churches take this a step further. They argue that in terms of worldly success-with which this form of Christianity is so concerned-there is no difference also between male and female believers. That is to say, 'success' and 'prosperity' do not depend on gender" (p. 84). Gifford (2004a) also notes that the message of winning is frequently directed at women. He relays a sermon by Pastor Mensa Otabil on 2 August 2002: “Most of you women have great potential but you will die pathetic creatures ... A woman's lot is not to depend on a man. Have your own house, car ... I'm looking for purpose-driven, achievement-oriented women" (Gifford 2004a, p. 184).

However, a woman is still expected to "submit" to her husband (Biblia n.d.) and in fact this can become a strategy to personal success itself, with the motto of the Pastors' Wives and Women in Ministry Association being “Helpmeet! By his side!" (Soothill 2010, p. 84). Bawa (2017) also describes the role of the church in reinforcing this submissiveness, ${ }^{5}$ noting a particular instance of "Arch Bishop" Duncan Williams, the head pastor of a famous Pentecostal church that many would expect to be progressive, who in a 2014 sermon, "stated that women ought to be grateful to men who married them since that validated them as women. He suggested that, given the statistics of a relatively high number of women to men (7:1 to be precise), married women were to be 'thankful and stop complaining'; unmarried women on the other hand were chided to be submissive in order to be considered marriageable" (ibid., p. 11).

Thus, the relationship between the Charismatic movement and female empowerment is complex and unresolved in the literature. This study takes an empirical approach, testing whether differences in women's empowerment, as measured by women's decision-making power, exist both before and after controlling for socioeconomic factors and wealth.

3 In this context, born-again refers to Pentecostal-style belief and practice.

4 Bawa (2017) argues that Soothill (2010) underestimates the potential effect of women in these positions, writing, "while visibility is not synonymous with positive social transformation in gender relations, it opens up spaces of possibilities and dialog for future entry of females into zones otherwise reserved for males in the Ghanaian society": p. 7.

5 She draws on fieldwork to show how deep knowledge of the Bible for self-identified Christians can be used to overcome these inequalities but notes that this is dependent upon socioeconomic status. 


\section{Measuring Women's Empowerment}

Golla et al. (2011) define women's economic empowerment as having "both the ability to succeed and advance economically and the power to make and act on economic decisions," (p. 4) and the two are connected. For example, skills and resources that allow women to advance economically, such as those taught in school, can lead to power and agency; but possessing power and agency can enable women to obtain skills and resources. This is all done in the context of norms and institutions (ibid). Measuring women's empowerment is therefore not a simple task and there are pros and cons to any method of doing so. This is made more complex with limited data availability in datasets that report religious denomination. The 2014 Ghana Demographic Health Survey (DHS) was used in this study, which does not contain data on the distribution of household asset ownership (used to measure bargaining power), earnings, or spending, and has limited data on domestic violence. ${ }^{6}$ However, the DHS does contain five questions on decision-making power, which measure the latter part of Golla et al.'s definition of empowerment: women's power to make and act on economic decisions. Within the possible power and agency indicators outlined by Golla et al., these decision-making questions address "control over assets" (spending of their own or their husband's earnings), "agency/decision-making" (large household purchases), and "autonomy and ability" (visits to family and relatives). Healthcare decision making spans both "agency/decision-making" and "gender norms" (p. 8).

I chose to focus this analysis on a women's empowerment measure that captures power and agency rather than resources and skills for two reasons. First, I believe it provides a more interesting theoretical contrast to the focus on female submissiveness in the Ghanaian Pentecostal Churches. Second, although I am able to control for some skills and resources-namely, education and employment status, number of children, and wealth-I do not believe these alone provide a rich enough proxy for empowerment to justify their use as dependent variables. As Oduro et al. (2015) discuss, empirical evidence is mixed in regard to labor market activities and empowerment as measured by intimate partner violence, and feminist economists have questioned the theoretical links between a woman's education, employment, income and empowerment (pp. 4-5).

\section{Data}

This study used the International Public Use Microdata Series, or IPUMS (Minnesota Population Center 2017) recode of Demographic Health Survey (DHS) data from the 2014 Ghana dataset. The DHS asks women who are married or living with a partner about their role in making decisions related to large household purchases, visits to family or relatives, spending of their own or their husband's earnings, and their own health care ${ }^{7}$. The dependent variable is a woman's decision-making power, coded as a 1 if the woman reports that she makes the decisions alone or jointly with her partner and 0 if she does not. Information on years of education, the total number of living children born, woman's age, and dichotomous variables were also included, with 1 representing an urban status, whether a woman has worked in the last 7 days, whether there is a female head of household, and regional locations, and 0 representing the absence of that variable. The DHS surveys include information on household assets and use this information to construct a wealth index, which is reported as wealth quintiles. I included wealth quintiles with the poorest quintile as the base group.

Table 1 reports means for religious denominations. After dropping observations with missing, incomplete, or unclear answers (135 observations, making up $2.5 \%$ of the sample) there are $5417^{8}$ women in the sample. The DHS has country specific answers to the question, "What is your religion?" with the options in the Ghana DHS (2014) listed as "Catholic, Anglican, Methodist,

6 The DHS has some data available on attitudes toward women and violence, but because other datasets contain richer information on domestic violence, I will save this for future work.

7 Specifically, the questions read, "Who usually makes decisions about..." The DHS does not ask non-married or non-cohabiting women about decision-making power.

83940 women in the DHS sample are not married or cohabiting and are therefore not asked about decision-making power. 
Presbyterian, Pentecostal/Charismatic/Evangelical, Other Christian/unspecified/general, Islam, Traditional/Spiritual/Animist, No Religion, and Other." The Pentecostal/Charismatic/Evangelical group is the largest of the sample at 36\%, followed by Muslim women at 19\%. Traditional/Spiritualist women are $3 \%$, and $4 \%$ of women say they have no religion. I aggregated the Christian religions as Catholic, Anglican, Methodist, Presbyterian, Pentecostal/Charismatic/Evangelical, and Other Christian, and this group makes up $74 \%$ of the sample. Each denomination is coded as a dichotomous variable with 1 representing membership in the religion and 0 otherwise.

Table 1. Reported Religious Denomination in the Sample.

\begin{tabular}{cc}
\hline & Percentage of Sample \\
\hline Catholic & $14 \%$ \\
Presbyterian & $4 \%$ \\
Anglican & $1 \%$ \\
Methodist & $5 \%$ \\
Pentecostal & $36 \%$ \\
Other Christian & $12 \%$ \\
Muslim & $21 \%$ \\
Traditional/Spiritualist & $3 \%$ \\
No Religion & $4 \%$ \\
\hline
\end{tabular}

Table 2 reports decision-making power by religion. The number of observations varies for each dependent variable to represent women who answered questions on the relevant dependent variables. Results mirror the socioeconomic variables with the Pentecostal/Charismatic group in the low to middle range of the Christian religions for decision making. The Traditional/Spiritual/Animist group is at the low end of the spectrum, with the Muslim and No Religion groups having slightly higher decision-making power. All groups have relatively high scores for deciding where female earnings are spent and low scores for decisions regarding the use of husband's earnings, which could presumably be expected.

Table 3 reports means and standard deviations for independent variables. The Traditional/Spiritual/ Animist group has the lowest education and wealth, followed by the No Religion and Muslim groups. Of the Christian religions, the Methodist group has the highest levels of education and wealth and the Catholic has the lowest. The Pentecostal/Charismatic women are in the middle of the Christian subgroup for most variables. All groups have a relatively high number of women who work, with the Traditional/Spiritual/Animist group at the top. 
Table 2. Female Decision-Making Power by Religious Denomination.

\begin{tabular}{|c|c|c|c|c|c|c|c|c|c|}
\hline & Catholic & Presbyterian & Anglican & Methodist & $\begin{array}{c}\text { Pentecostal/Charismatic/ } \\
\text { Evangelical }\end{array}$ & $\begin{array}{l}\text { Other } \\
\text { Christian }\end{array}$ & Muslim & $\begin{array}{c}\text { Traditional/Spiritual/ } \\
\text { Animist }\end{array}$ & No Religion \\
\hline Big Household Purchases & $77.89 \%$ & $82.23 \%$ & $80.00 \%$ & $82.44 \%$ & $76.42 \%$ & $82.28 \%$ & $64.09 \%$ & $59.65 \%$ & $73.40 \%$ \\
\hline Observations & 760 & 242 & 35 & 262 & 1925 & 666 & 1125 & 171 & 203 \\
\hline Family Visit & $88.34 \%$ & $90.08 \%$ & $88.89 \%$ & $93.54 \%$ & $87.55 \%$ & $89.69 \%$ & $79.61 \%$ & $73.84 \%$ & $86.21 \%$ \\
\hline Observations & 763 & 242 & 36 & 263 & 1936 & 669 & 1133 & 172 & 203 \\
\hline Female Earnings & $95.62 \%$ & $92.97 \%$ & $95.00 \%$ & $96.07 \%$ & $94.76 \%$ & $93.29 \%$ & $95.31 \%$ & $92.19 \%$ & $89.29 \%$ \\
\hline Observations & 479 & 185 & 20 & 178 & 1430 & 477 & 597 & 128 & 140 \\
\hline Husband Earnings & $50.60 \%$ & $42.26 \%$ & $52.94 \%$ & $57.14 \%$ & $48.74 \%$ & $52.36 \%$ & $34.68 \%$ & $26.19 \%$ & $33.66 \%$ \\
\hline Observations & 755 & 239 & 34 & 259 & 1900 & 657 & 1116 & 168 & 202 \\
\hline Female Healthcare & $82.52 \%$ & $83.06 \%$ & $75.00 \%$ & $84.79 \%$ & $77.75 \%$ & $82.73 \%$ & $74.05 \%$ & $59.41 \%$ & $69.46 \%$ \\
\hline Observations & 761 & 242 & 36 & 263 & 1924 & 666 & 1129 & 170 & 203 \\
\hline
\end{tabular}

Means are reported for women who are married or cohabit who demonstrate shared or solo decision-making power in each category. 
Table 3. Independent Variable Summary Statistics.

\begin{tabular}{|c|c|c|c|c|c|c|c|c|c|}
\hline & Catholic & Presbyterian & Anglican & Methodist & $\begin{array}{c}\text { Pentecostal/Charismatic/ } \\
\text { Evangelical }\end{array}$ & $\begin{array}{l}\text { Other } \\
\text { Christian }\end{array}$ & Muslim & $\begin{array}{c}\text { Traditional/Spiritual/ } \\
\text { Animist }\end{array}$ & No Religion \\
\hline Years of Education & $\begin{array}{l}5.464 \\
(5.439)\end{array}$ & $\begin{array}{c}7.905 \\
(4.776)\end{array}$ & $\begin{array}{c}7.333 \\
(4.329)\end{array}$ & $\begin{array}{c}8.639 \\
(4.539)\end{array}$ & $\begin{array}{c}6.352 \\
(4.782)\end{array}$ & $\begin{array}{c}6.882 \\
(4.731)\end{array}$ & $\begin{array}{c}3.177 \\
(4.686)\end{array}$ & $\begin{array}{c}1.140 \\
(2.700)\end{array}$ & $\begin{array}{c}2.158 \\
(3.169)\end{array}$ \\
\hline Urban & $\begin{array}{c}0.324 \\
(0.468)\end{array}$ & $\begin{array}{c}0.521 \\
(0.501)\end{array}$ & $\begin{array}{c}0.444 \\
(0.504)\end{array}$ & $\begin{array}{c}0.479 \\
(0.501)\end{array}$ & $\begin{array}{c}0.456 \\
(0.498)\end{array}$ & $\begin{array}{c}0.513 \\
(0.500)\end{array}$ & $\begin{array}{c}0.550 \\
(0.498)\end{array}$ & $\begin{array}{c}0.145 \\
(0.354)\end{array}$ & $\begin{array}{c}0.256 \\
(0.438)\end{array}$ \\
\hline Number of Children & $\begin{array}{c}3.168 \\
(1.941)\end{array}$ & $\begin{array}{c}3.017 \\
(1.958)\end{array}$ & $\begin{array}{c}3.194 \\
(1.895)\end{array}$ & $\begin{array}{c}2.780 \\
(1.995)\end{array}$ & $\begin{array}{c}3.080 \\
(1.969)\end{array}$ & $\begin{array}{c}3.302 \\
(2.043)\end{array}$ & $\begin{array}{l}3.300 \\
(2.015)\end{array}$ & $\begin{array}{c}4.547 \\
(2.137)\end{array}$ & $\begin{array}{c}3.759 \\
(2.136)\end{array}$ \\
\hline Married & $\begin{array}{c}0.818 \\
(0.386)\end{array}$ & $\begin{array}{c}0.665 \\
(0.473)\end{array}$ & $\begin{array}{c}0.611 \\
(0.494)\end{array}$ & $\begin{array}{c}0.745 \\
(0.437)\end{array}$ & $\begin{array}{c}0.706 \\
(0.456)\end{array}$ & $\begin{array}{c}0.738 \\
(0.440)\end{array}$ & $\begin{array}{c}0.937 \\
(0.244)\end{array}$ & $\begin{array}{c}0.802 \\
(0.399)\end{array}$ & $\begin{array}{c}0.764 \\
(0.426)\end{array}$ \\
\hline Age & $\begin{array}{l}33.404 \\
(8.040)\end{array}$ & $\begin{array}{l}35.244 \\
(8.049)\end{array}$ & $\begin{array}{l}34.028 \\
(7.737)\end{array}$ & $\begin{array}{l}33.540 \\
(7.995)\end{array}$ & $\begin{array}{l}33.381 \\
(7.875)\end{array}$ & $\begin{array}{l}34.112 \\
(7.968)\end{array}$ & $\begin{array}{l}33.303 \\
(8.104)\end{array}$ & $\begin{array}{l}35.151 \\
(8.008)\end{array}$ & $\begin{array}{l}34.562 \\
(8.336)\end{array}$ \\
\hline Female Household Head & $\begin{array}{c}0.152 \\
(0.359)\end{array}$ & $\begin{array}{c}0.252 \\
(0.435)\end{array}$ & $\begin{array}{c}0.167 \\
(0.378)\end{array}$ & $\begin{array}{c}0.262 \\
(0.441)\end{array}$ & $\begin{array}{c}0.199 \\
(0.399)\end{array}$ & $\begin{array}{c}0.242 \\
(0.429)\end{array}$ & $\begin{array}{c}0.116 \\
(0.320)\end{array}$ & $\begin{array}{c}0.105 \\
(0.307)\end{array}$ & $\begin{array}{c}0.163 \\
(0.370)\end{array}$ \\
\hline Wealth 1 & $\begin{array}{c}0.438 \\
(0.496)\end{array}$ & $\begin{array}{c}0.136 \\
(0.344)\end{array}$ & $\begin{array}{c}0.167 \\
(0.378)\end{array}$ & $\begin{array}{c}0.076 \\
(0.266)\end{array}$ & $\begin{array}{c}0.222 \\
(0.415)\end{array}$ & $\begin{array}{c}0.126 \\
(0.332)\end{array}$ & $\begin{array}{c}0.362 \\
(0.481)\end{array}$ & $\begin{array}{c}0.797 \\
(0.404)\end{array}$ & $\begin{array}{c}0.522 \\
(0.501)\end{array}$ \\
\hline Wealth 2 & $\begin{array}{c}0.180 \\
(0.384)\end{array}$ & $\begin{array}{c}0.203 \\
(0.403)\end{array}$ & $\begin{array}{c}0.139 \\
(0.351)\end{array}$ & $\begin{array}{c}0.236 \\
(0.425)\end{array}$ & $\begin{array}{c}0.190 \\
(0.392)\end{array}$ & $\begin{array}{c}0.209 \\
(0.407)\end{array}$ & $\begin{array}{c}0.190 \\
(0.392)\end{array}$ & $\begin{array}{c}0.145 \\
(0.354)\end{array}$ & $\begin{array}{c}0.227 \\
(0.420)\end{array}$ \\
\hline Wealth 3 & $\begin{array}{c}0.147 \\
(0.354)\end{array}$ & $\begin{array}{c}0.219 \\
(0.414)\end{array}$ & $\begin{array}{c}0.278 \\
(0.454)\end{array}$ & $\begin{array}{c}0.202 \\
(0.402)\end{array}$ & $\begin{array}{c}0.192 \\
(0.394)\end{array}$ & $\begin{array}{c}0.242 \\
(0.429)\end{array}$ & $\begin{array}{c}0.182 \\
(0.386)\end{array}$ & $\begin{array}{c}0.041 \\
(0.198)\end{array}$ & $\begin{array}{c}0.133 \\
(0.340)\end{array}$ \\
\hline Wealth 4 & $\begin{array}{c}0.122 \\
(0.327)\end{array}$ & $\begin{array}{c}0.161 \\
(0.368)\end{array}$ & $\begin{array}{c}0.222 \\
(0.422)\end{array}$ & $\begin{array}{c}0.175 \\
(0.381)\end{array}$ & $\begin{array}{c}0.189 \\
(0.392)\end{array}$ & $\begin{array}{c}0.224 \\
(0.417)\end{array}$ & $\begin{array}{c}0.171 \\
(0.377)\end{array}$ & $\begin{array}{c}0.017 \\
(0.131)\end{array}$ & $\begin{array}{c}0.099 \\
(0.299)\end{array}$ \\
\hline Wealth 5 & $\begin{array}{c}0.114 \\
(0.318)\end{array}$ & $\begin{array}{c}0.281 \\
(0.450)\end{array}$ & $\begin{array}{c}0.194 \\
(0.401)\end{array}$ & $\begin{array}{c}0.312 \\
(0.464)\end{array}$ & $\begin{array}{c}0.208 \\
(0.406)\end{array}$ & $\begin{array}{c}0.199 \\
(0.399)\end{array}$ & $\begin{array}{c}0.095 \\
(0.294)\end{array}$ & $\begin{array}{l}0.000 \\
0.000\end{array}$ & $\begin{array}{c}0.020 \\
(0.139)\end{array}$ \\
\hline Employed & $\begin{array}{c}0.856 \\
(0.352)\end{array}$ & $\begin{array}{c}0.843 \\
(0.365)\end{array}$ & $\begin{array}{c}0.778 \\
(0.422)\end{array}$ & $\begin{array}{c}0.856 \\
(0.352)\end{array}$ & $\begin{array}{c}0.850 \\
(0.358)\end{array}$ & $\begin{array}{c}0.848 \\
(0.360)\end{array}$ & $\begin{array}{c}0.817 \\
(0.387)\end{array}$ & $\begin{array}{c}0.913 \\
(0.283)\end{array}$ & $\begin{array}{c}0.842 \\
(0.365)\end{array}$ \\
\hline Observations & 763 & 242 & 36 & 263 & 1936 & 669 & 1133 & 172 & 203 \\
\hline
\end{tabular}

Standard deviations in parentheses. Regional dummy variables also included in analysis. 


\section{Econometric Methodology and Results}

Because decision-making variables mirror socioeconomic variables, with Traditional/Spiritual/ Animist women at a disadvantage and Christian women, particularly Methodists, at an advantage, it is not clear whether factors like education, work status, or wealth are driving the women's empowerment results. For example, women in the Methodist religion may be more empowered simply because they have higher levels of education. To control for this, I ran logistic regressions that included the independent variables detailed above. A logistic model is appropriate when the dependent variable is binary, in this case a 1 representing some decision-making power and 0 representing none. The model is,

$$
y_{i}=\beta_{0}+\beta x_{i}+\text { Religion }_{i}+\varepsilon_{i}
$$

where $y$ represents decision-making power, $\mathrm{x}$ represents independent variables as described above, and Religion contains a set of dummy variables for each woman's religious denomination. $\beta_{0}$ and $\varepsilon_{\mathrm{i}}$ are intercept and stochastic error terms, respectively. I used survey weights ${ }^{9}$ to control for the sampling procedure.

Table 4 shows the results. With a logistic regression, coefficients do not have an intuitive interpretation so, where appropriate, I provide marginal effects for parameters of interest. Panel A shows the entire sample with Traditional/Spiritual/Animist religions as a base group. The only regression for which the Pentecostal/Charismatic/Evangelical variable is significant is for family visit decisions. The marginal effect for this is $7.03 \%$ (from $83.7 \%$ to $90.8 \%$, holding other variables constant). However, it is unclear whether the Pentecostal/Charismatic group is different from the Christian variables because each of these (except Anglican) is also significantly higher than the Traditional/Spiritual/Animist group.

To further explore this result, I ran the same regressions for only the Christian subgroup with all non-Pentecostal/Charismatic Christians aggregated together as the base group. The results show that women who identify as Pentecostal/Charismatic/Evangelical have significantly lower decision-making power for big household purchases and for female health care, holding all other variables constant, although the big purchases variable is only marginally significant. The marginal effect for the big household purchases regression is $-4.3 \%$ (from $79.7 \%$ to $75.4 \%$ ) and the marginal effect for the female healthcare regression is $-3.3 \%$ (from $81.3 \%$ to $78.0 \%$ ). This indicates that women who identify as Pentecostal/Charismatic/Evangelical have less decision-making power than other Christian women.

Other independent variables show that, generally, women who have more education, who work, and who live in female-headed households consistently have more decision-making power. Age is only significant for major household purchases, and marital status is only significant for husband's earnings and female healthcare. Wealth dummy variables generally show a positive correlation between wealth and decision-making power, although results are not significant for many quartiles, particularly for the big household purchases and female healthcare decisions.

9 In particular, I ran tests of sample weights, which indicate weights are appropriate for respondents' own and their partners' earnings, along with female healthcare. I used weights for all regressions to keep results consistent. 
Table 4. Results.

\begin{tabular}{|c|c|c|c|c|c|c|c|c|c|c|}
\hline & (1) & (2) & (3) & (4) & (5) & (6) & (7) & (8) & (9) & (10) \\
\hline Sample & All & All & All & All & All & Christian & Christian & Christian & Christian & Christian \\
\hline \multirow[t]{2}{*}{ Religion Base Group } & \multicolumn{3}{|c|}{ Traditional/Spiritual/Animist } & \multicolumn{6}{|c|}{ Non-Pentecostal Christian } & \\
\hline & $\begin{array}{l}\text { Big Household } \\
\text { Purchases }\end{array}$ & Family Visit & $\begin{array}{c}\text { Female } \\
\text { Earnings }\end{array}$ & $\begin{array}{c}\text { Husband's } \\
\text { Earnings }\end{array}$ & $\begin{array}{c}\text { Female } \\
\text { Healthcare }\end{array}$ & $\begin{array}{l}\text { Big Household } \\
\text { Purchases }\end{array}$ & Family Visit & $\begin{array}{c}\text { Female } \\
\text { Earnings }\end{array}$ & $\begin{array}{c}\text { Husband's } \\
\text { Earnings }\end{array}$ & $\begin{array}{l}\text { Female } \\
\text { Healthcare }\end{array}$ \\
\hline Muslim & $\begin{array}{l}0.0449 \\
(0.279)\end{array}$ & $\begin{array}{c}0.280 \\
(0.308)\end{array}$ & $\begin{array}{l}0.414 \\
(0.500)\end{array}$ & $\begin{array}{c}-0.0199 \\
(0.375)\end{array}$ & $\begin{array}{c}0.367 \\
(0.263)\end{array}$ & & & & & \\
\hline Catholic & 0.402 & 0.750 ** & 0.655 & 0.255 & $0.587^{* *}$ & & & & & \\
\hline & $(0.288)$ & $(0.336)$ & $(0.475)$ & $(0.354)$ & $(0.285)$ & & & & & \\
\hline Anglican & 0.379 & 1.011 & 0.361 & 0.556 & -0.205 & & & & & \\
\hline & $(0.602)$ & $(0.656)$ & (1.144) & $(0.538)$ & $(0.515)$ & & & & & \\
\hline Methodist & $\begin{array}{r}0.386 \\
(0.364)\end{array}$ & $\begin{array}{c}1.478^{* * *} \\
(0.426)\end{array}$ & $\begin{array}{r}0.759 \\
(0.592)\end{array}$ & $\begin{array}{c}0.131 \\
(0.393)\end{array}$ & $\begin{array}{l}0.326 \\
(0.321)\end{array}$ & & & & & \\
\hline \multirow{2}{*}{ Pentecostal/Charismatic/Evangelical } & 0.213 & $0.686^{* *}$ & 0.271 & 0.0479 & $\begin{array}{c}(0.321) \\
0.179\end{array}$ & $-0.267 * *$ & -0.132 & -0.0343 & -0.0878 & $-0.230 *$ \\
\hline & $(0.267)$ & $(0.298)$ & $(0.442)$ & $(0.348)$ & $(0.243)$ & $(0.128)$ & $(0.150)$ & $(0.210)$ & $(0.0984)$ & $(0.126)$ \\
\hline \multirow[t]{2}{*}{ Other Christian } & $0.590^{* *}$ & $0.736^{* *}$ & 0.184 & 0.223 & 0.396 & & & & & \\
\hline & $\begin{array}{c}(0.299) \\
0.461\end{array}$ & $\begin{array}{l}(0.346) \\
0.708 *\end{array}$ & $\begin{array}{l}(0.476) \\
0.0286\end{array}$ & $\begin{array}{l}(0.360) \\
-0310\end{array}$ & $(0.281)$ & & & & & \\
\hline Presbyterian & $\begin{array}{c}0.461 \\
(0.346)\end{array}$ & $\begin{array}{l}0.708^{*} \\
(0.384)\end{array}$ & $\begin{array}{l}0.0286 \\
(0.524)\end{array}$ & $\begin{array}{l}-0.310 \\
(0.372)\end{array}$ & $\begin{array}{c}0.339 \\
(0.325)\end{array}$ & & & & & \\
\hline No Religion & $\begin{array}{c}0.269 \\
(0.323)\end{array}$ & $\begin{array}{l}0.841^{* * *} \\
(0.413)\end{array}$ & $\begin{array}{l}0.0986 \\
(0.408)\end{array}$ & $\begin{array}{l}-0.229 \\
(0.401)\end{array}$ & $\begin{array}{c}0.209 \\
(0.306)\end{array}$ & & & & & \\
\hline Years of Education & $0.0387 * * * *$ & 0.00582 & $\begin{array}{l}0.0323 \\
0.0197\end{array}$ & $0.0367^{* * * *}$ & $0.0578 * * * *$ & $0.0420 * * *$ & $\begin{array}{l}0.00402 \\
(0.0178)\end{array}$ & 0.0460 ** & 0.0416 *** & $0.0507 * * *$ \\
\hline \multirow{2}{*}{ Wealth 2} & 0.122 & $0.435 * *$ & $0.478 * *$ & $0.294^{* *}$ & 0.253 & 0.237 & $0.764^{* * * *}$ & 0.424 & 0.184 & $0.360^{*}$ \\
\hline & $(0.162)$ & $(0.196)$ & $(0.240)$ & $(0.138)$ & $(0.157)$ & $(0.207)$ & $(0.276)$ & $(0.303)$ & $(0.160)$ & $(0.209)$ \\
\hline \multirow[t]{2}{*}{ Wealth 3} & 0.209 & $0.618^{* *}$ & $0.715^{* *}$ & 0.162 & 0.248 & $0.424^{*}$ & $1.014^{* * *}$ & $0.833^{* *}$ & 0.0282 & 0.290 \\
\hline & $(0.189)$ & $(0.247)$ & $(0.303)$ & $(0.160)$ & $(0.182)$ & $(0.226)$ & $(0.335)$ & $(0.368)$ & $(0.180)$ & $(0.238)$ \\
\hline \multirow[t]{2}{*}{ Wealth 4} & 0.225 & 0.662 ** & 0.269 & 0.255 & -0.00691 & 0.343 & 0.964 ** & 0.251 & 0.134 & -0.0200 \\
\hline & $(0.222)$ & $(0.301)$ & $(0.294)$ & $(0.213)$ & $(0.220)$ & $(0.267)$ & $(0.398)$ & $(0.353)$ & $(0.223)$ & $(0.285)$ \\
\hline \multirow[t]{2}{*}{ Wealth 5} & 0.105 & $0.928^{* * * *}$ & $1.136^{* * * *}$ & 0.178 & -0.0696 & 0.140 & $1.225^{* * * *}$ & $1.116^{* *}$ & 0.00124 & -0.104 \\
\hline & $(0.255)$ & $(0.341)$ & $(0.430)$ & $(0.257)$ & $(0.264)$ & $(0.306)$ & $(0.440)$ & $(0.459)$ & $(0.271)$ & $(0.324)$ \\
\hline \multirow[t]{2}{*}{ Urban } & -0.0379 & -0.146 & 0.161 & $-0.252 *$ & -0.197 & -0.0656 & -0.321 & 0.0234 & -0.218 & -0.248 \\
\hline & $(0.162)$ & $(0.176)$ & $(0.235)$ & $(0.140)$ & $(0.156)$ & $(0.191)$ & $(0.213)$ & $(0.249)$ & $(0.146)$ & $(0.187)$ \\
\hline \multirow[t]{2}{*}{ Number of Children } & $0.0567^{* *}$ & 0.0361 & 0.00929 & 0.0213 & 0.0447 & 0.0584 & -0.00432 & -0.0121 & 0.0268 & 0.0493 \\
\hline & $(0.0288)$ & $(0.0331)$ & $(0.0546)$ & $(0.0281)$ & $(0.0271)$ & $(0.0382)$ & $(0.0408)$ & $(0.0682)$ & $(0.0342)$ & $(0.0345)$ \\
\hline \multirow[t]{2}{*}{ Married } & 0.130 & 0.184 & 0.147 & $0.408^{* * *}$ & $0.365 * * *$ & 0.172 & 0.138 & 0.242 & $0.465 * * *$ & $0.463 * * *$ \\
\hline & $(0.114)$ & $(0.125)$ & $(0.207)$ & $(0.0995)$ & $(0.118)$ & $(0.127)$ & $(0.135)$ & $(0.227)$ & $(0.105)$ & $(0.135)$ \\
\hline Age & $0.0246^{* * * *}$ & 0.0112 & 0.0157 & -0.00536 & $0.0153^{* *}$ & $0.0243^{* * *}$ & 0.0126 & 0.0154 & -0.00843 & $0.0158^{*}$ \\
\hline \multirow{2}{*}{ Female HH Head } & $\begin{array}{l}(0.00669) \\
0.500 * * *\end{array}$ & $\begin{array}{l}(0.00744) \\
0.473 * * *\end{array}$ & $\begin{array}{c}(0.0145) \\
0.244\end{array}$ & $\begin{array}{l}(0.00698) \\
-0.359^{* * *}\end{array}$ & $\begin{array}{c}(0.00748) \\
0.309 * *\end{array}$ & $\begin{array}{l}(0.00803) \\
0.482^{* * * *}\end{array}$ & $\begin{array}{l}(0.0106) \\
0.419^{* *}\end{array}$ & $\begin{array}{c}(0.0169) \\
0.261\end{array}$ & $\begin{array}{l}(0.00728) \\
-0.0321^{* * *}\end{array}$ & $(0.00929)$ \\
\hline & $(0.128)$ & $(0.156)$ & $(0.228)$ & $(0.0967)$ & $(0.125)$ & $(0.136)$ & $(0.172)$ & $(0.245)$ & $(0.106)$ & $(0.133)$ \\
\hline \multirow[t]{2}{*}{ Employed } & $0.729 * * *$ & $0.663^{* * * *}$ & -0.437 & $0.383 * * *$ & $0.902 * * *$ & $0.726 * * *$ & $0.693^{* * * *}$ & -0.547 & $0.434 * * *$ & $0.900 * * *$ \\
\hline & $(0.114)$ & $(0.136)$ & $(0.522)$ & $(0.124)$ & $(0.133)$ & $(0.139)$ & $(0.177)$ & $(0.668)$ & $(0.141)$ & $(0.159)$ \\
\hline \multirow[t]{2}{*}{ Constant } & $-1.607 * * *$ & -0.723 & $1.369^{*}$ & $-1.154^{* * * *}$ & $-1.431^{* * * *}$ & $-1.149 * * *$ & 0.0460 & $1.717^{* *}$ & $-0.927^{* * * *}$ & $-0.904^{* *}$ \\
\hline & $(0.396)$ & $(0.451)$ & $(0.779)$ & $(0.430)$ & $(0.403)$ & $(0.362)$ & $(0.513)$ & $(0.872)$ & $(0.280)$ & $(0.399)$ \\
\hline F-Statistic & $11.97^{* * * *}$ & $6.42 * * *$ & $1.91^{* * *}$ & $7.34 * * *$ & $9.65 * * *$ & $11.95^{* * * *}$ & $5.8 * * *$ & $1.88^{* * *}$ & $7.88^{* * * *}$ & $10.35 * * *$ \\
\hline Prob $>$ F & 0.000 & 0.000 & 0.004 & 0.000 & 0.000 & 0.000 & $\begin{array}{l}0.000 \\
0.000\end{array}$ & 0.012 & 0.000 & 0.000 \\
\hline Observations & 5389 & 5417 & 3634 & 5330 & 5394 & 3890 & 3909 & 2769 & 3844 & 3892 \\
\hline
\end{tabular}

Region dummy variables also included. Standard errors in parentheses. ${ }^{* *} p<0.01{ }^{* *} p<0.05,{ }^{*} p<0.1$. 


\section{Conclusions/Discussion}

This study is the first to test for differences in empowerment for women who identify as Pentecostal in Africa. Though some argue that the spread of Pentecostalism empowers women, there exists a "Pentecostal Gender Paradox" (Martin 2001) where complex messages in the church complicate this link. In Ghana, messages of individuality, equal access to material wealth, and female leadership theoretically enhance women's empowerment, while messages of submissiveness to men diminish it. Using data from the 2014 Ghana Demographic Health Survey, I tested for differences in decision-making power for married/cohabiting women by religion. Raw data show that women who identify as Pentecostal/Charismatic/Evangelical are in the center to low end of the distribution for Christians but have more decision-making power than most non-Christians. Once education, wealth, and other socioeconomic variables are controlled for, Pentecostal women have more decision-making power than the Traditional/Spiritual/Animist base group only for family visits. Among the Christian subgroup, they have less decision-making power than other Christians for big household purchases and female healthcare.

To the extent that decision-making power represents female empowerment, these results indicate that women who identify as Pentecostal/Charismatic/Evangelical are less empowered than other Christians when it comes to household purchases and healthcare. It is important to note, however, that this does not indicate that membership in these churches leads to lower levels of female empowerment. First, there may be missing variables, such as income, that are driving results. Second, women who are less empowered may be drawn to Pentecostal churches, which would lead to the negative estimates. It is also worth noting that even if a perfect measure of empowerment existed, it would not necessarily indicate fully favorable outcomes for women. For example, as Mahmud et al. (2012) point out, greater economic visibility may expose women to violence; or a greater role in decision making may cause men to withdraw support for things like health care. Thus, it is important to remember that although greater women's empowerment is a desirable outcome, it is by no means a holistic measure of well-being.

Even in light of these caveats, the finding that Pentecostal women are less empowered than other Christians in Ghana seems puzzling in the face of Beck and Gundersen's (2016) finding that Pentecostal women have higher earned income than the Presbyterian base group. One way of reconciling the two findings relates to Carvalho's (2012) work on female veiling in Muslim societies. He describes the dramatic increase in veiling from the 1970s and notes the puzzling fact that it originates among urban, educated, middle-class women who work outside the home. To reconcile the two, he developed a model where women use veiling to pursue economic opportunities while avoiding disapproval in their communities. Similarly, Mate (2002) analysed teachings in prominent women's organizations in Zimbabwean Pentecostal churches and found that they use notions of domesticity to "tighten the patriarchal grip on women" (p. 549) but also encourage modernity outside the home. In this case, it is possible that Ghanaian Pentecostal women maintain submissiveness in marriage so that they can pursue economic outcomes elsewhere. For example, they may choose to obtain higher paying employment, land ownership, or other assets while preserving gender roles within the home. In light of this possibility, it would be interesting to explore whether bargaining power, as measured by ownership of assets, is correlated with religious denomination or to test the relationship between religious denomination and empowerment using a dataset that also contains earnings information.

While data limitations prevent me from exploring these pathways here, my hope is that this analysis motivates both quantitative and qualitative work. In addition to the possibilities for quantitative studies described above, qualitative researchers could evaluate how economic behavior relates to gender norms in both Pentecostal and non-Pentecostal churches.

As the first study to explicitly test for female empowerment in African Pentecostal churches, however, I believe the results are relevant to scholars of religion and gender studies. Until now, Soothill (2010) notes that most scholars have possessed an "'enthusiasm' fueled by the perception that [the global Charismatic movement] will, in some sense, 'empower' its female adherents" (p. 82). This analysis shows that such a perception may not be supported by the data. 
Conflicts of Interest: The author declares no conflict of interest.

\section{References}

Addai, Isaac. 2000. Religious affiliation and sexual initiation among Ghanian Women. Review of Religious Research 4: 328-43. [CrossRef]

Anderson, Allan H. 2013. To the Ends of the Earth: Pentecostalism and the Transformation of World Christianity. Oxford: Oxford University Press.

Awumbila, Mariama. 2006. Gender equality and poverty in Ghana: Implications for Poverty Reduction Strategies. GeoJournal 67: 149-61. [CrossRef]

Bawa, Sylvia. 2017. Christianity, Tradition, and Gender Inequality in Postcolonial Ghana. African Geographical Review, 1-16. [CrossRef]

Beck, Sedefka V., and Sara J. Gundersen. 2016. A Gospel of Prosperity? An Analysis of the Relationship between Religion and Earned Income in Ghana, the Most Religious Country in the World: Religion and Earned Income in Ghana. Journal for the Scientific Study of Religion 55: 105-29. [CrossRef]

Biblia. n.d. Ephesians 5: 22-24. Available online: http:/ / biblia.com/bible/esv/Eph5.22-24 (accessed on 16 March 2018).

Boateng, Godfred Odei, Vincent Zubedaar Kuuire, Mengieng Ung, Jonathan Anim Amoyaw, Frederick Ato Armah, and Isaac Luginaah. 2014. Women's empowerment in the context of millennium development goal 3: A case study of married women in Ghana. Social Indicators Research 115: 137-58. [CrossRef]

Carvalho, Jean-Paul. 2012. Veiling. Quarterly Journal of Economics 128: 337-70. [CrossRef]

Gifford, Paul. 2004a. Ghana's New Christianity: Pentecostalism in a Globalizing African Economy. Bloomington: Indiana University Press.

Gifford, Paul. 2004b. Persistence and Change in Contemporary African Religion. Social Compass 51: 169-76. [CrossRef]

Golla, Anne Marie, Anju Malhotra, Priya Nanda, and Rekha Mehra. 2011. Understanding and Measuring Women's Economic Empowerment. Washington: International Center for Research on Women (ICRW).

Heaton, Tim, James Spencer, and Oheneba-Sakyi Yaw. 2009. Religion and Socioeconomic Attainment in Ghana. Review of Religious Research 17: 71-86.

Lawless, Elaine J. 1988. Handmaidens of the Lord: Pentecostal Women Preachers and Traditional Religion. Philadelphia: University of Pennsylvania Press.

Mahmud, Simeen, Nirali M. Shah, and Stan Becker. 2012. Measurement of Women's Empowerment in Rural Bangladesh. World Development 40: 610-19. [CrossRef] [PubMed]

Martin, Bernice. 2001. The Pentecostal Gender Paradox: A Cautionary Tale for the Sociology of Religion. In The Blackwell Companion to Sociology of Religion. Edited by Richard K. Fenn. Malden: Blackwell Publishing Ltd., pp. 52-66. [CrossRef]

Mate, Rekopantswe. 2002. Wombs as God's Laboratories: Pentecostal Discourses of Femininity in Zimbabwe. Africa: Journal of the International African Institute 72: 549-68. [CrossRef]

Minnesota Population Center. 2017. Integrated Public Use Microdata Series, International: Version 6. Demographic Health Survey, Ghana 2014. Minneapolis: University of Minnesota. [CrossRef]

Oduro, Abena D., Carmen Diana Deere, and Zachary B. Catanzarite. 2015. Women's Wealth and Intimate Partner Violence: Insights from Ecuador and Ghana. Feminist Economics 21: 1-29. [CrossRef]

Powers, Janet Everts. 1999. Your daughters shall prophesy: Pentecostal hermeneutics and the empowerment of women. In The Globalisation of Pentecostalism: A Religion Made To Travel. Edited by Murray W. Dempster, Byron D. Klaus and Douglas Petersen. Oxford: Regnum Books International.

Soothill, Jane E. 2007. Gender, Social Change and Spiritual Power: Charismatic Christianity in Ghana. Leiden: Brill.

Soothill, Jane E. 2010. The Problem with 'Women's Empowerment': Female Religiosity in Ghana's Charismatic Churches. Studies in World Christianity 16: 82-99. [CrossRef] 
WIN-Gallup International. 2012. Global Index of Religion and Atheism. Available online: https://sidmennt. is / wp-content/uploads / Gallup-International-um-tr\%C3\%BA-og-tr\%C3\%BAleysi-2012.pdf (accessed on 16 March 2018).

Wrigley-Asante, Charlotte. 2008. Men are poor but women are poorer: Gendered poverty and survival strategies in the Dangme West District of Ghana. Norsk Geografisk Tidsskrift—Norwegian Journal of Geography 62: 161-70. [CrossRef] article distributed under the terms and conditions of the Creative Commons Attribution (CC BY) license (http://creativecommons.org/licenses/by/4.0/). 